\title{
INVESTOR RELATIONS TOOLS FOR BUSINESS IN SMART SPECIALIZATION STRATEGY
}

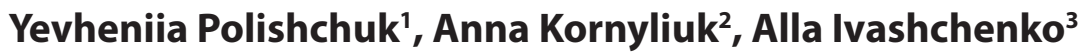

\begin{abstract}
Communication with investors is an important component in the activities of SMEs and large companies. Facing the new changes (development of digital technologies, COVID-19, smart specialization) the search for optimal tools of communication with investors becomes a priority for all key stakeholders of the investment process (business, academia, civil society, local authorities). The aim of the article is to identify effective communication tools for business and develop recommendations for their use in the context of smart specialization. Subject of research: investor relations of large, medium and small companies in the context of smart specialization. The main research methods are systemic (to build a system of investor relations tools) and analytical (to determine the IR tools among the studied companies; to analyze the tools of investor relations by using social media). As a result of the study, it is determined that the promotion of the Ukrainian companies through social networks is inactive (Facebook - 13\%, Instagram and Twitter - 4\%, YouTube - 5\% and Linkedln - 1\%). More than half of the surveyed companies indicate that the most common investor relations tools are news releases and presentations (71.4\%), answers to questions (61.1\%) and annual reports (52.7\%). In this article, smart specialization is considered as a common tool for communication between key stakeholders. It was determined that in the conditions of COVID19, they used the following tools: online dialogues, online conferences, online sessions, online workshops, online presentations, world cafes, annual lectures, online consultations, webinars (partner webinars). This study set out to explore investor relations tools in the context of smart specialization. In addition, such global tendencies were revealed as: IR boosting startups' transformation into large companies; increasing both the investors' interest to the companies and the requirements to corporate transparency promote using of IR tools; investor meetings via online platforms; impact of regional specifics on choosing IR tools of different companies. The results of the investigation show that Ukrainian companies have different IR politics. The main reasons why they use IR tools actively are their own internal requirements to the quality management and the need in external funding. Moreover, new legislation demands to the super advisory boards of public companies are reflected in using IR tools.
\end{abstract}

Key words: investor relations, smart specialization, large business, IPO, SMEs.

JEL Classification: G02, G11, M31

\section{Introduction}

The smart specialization approach involves the active communication of key participants in the innovation process: representatives of business, academia, civil society and local authorities. The implementation of the regional strategy, which is built on the principles of smart specialization, can bring the region to a new, more competitive level on a global scale. Smart specialization helps to connect the interests of investors who are focused on finding and implementing innovations with representatives of business and academia, which are essentially the main producers of innovation.

The problem of effective communication between these stakeholders is important and need to be solved immediately. Very often investors cannot find attractive projects in the regions, businesses and academics are not able to properly present

\footnotetext{
Corresponding author:

${ }^{1}$ Kyiv National Economic University named after Vadym Hetman, Ukraine.

E-mail: yivga_83@ukr.net

ORCID: https://orcid.org/0000-0002-6133-910X

ResearcherID: J-5444-2018

${ }^{2}$ Kyiv National Economic University named after Vadym Hetman, Ukraine.

E-mail: alla.ivaschenko@kneu.edu.ua

ORCID: https://orcid.org/0000-0001-8713-0681

${ }^{3}$ Kyiv National Economic University named after Vadym Hetman, Ukraine.

E-mail: anna.kornyliuk@kneu.edu.ua

ORCID: https://orcid.org/0000-0002-4599-7137
} 
their projects and also their performance in general. Representatives of civil society can also do effective promotion of their localities. Effective communication with investors is also needed while public-private partnerships, where key players are local authorities and investors.

The need for IR research in the context of smart specialization is sharp to the rapid development of digital technologies as well. This helps to speed up communication processes and attract more investors and full the economy with additional financial resources.

The situation around COVID-19 also forces to find the latest methods of communication. They are aimed not only at finding new investors, but also strengthening partnerships with other investors. All this is a prerequisite for researching investor relations, identifying best practices and applying their tools to promote different companies (big business and SMEs) at the regional, national and global levels.

The aim of the article is to identify effective communication tools for business and develop recommendations for their use in the context of smart specialization. Research questions are formulated around the issue of smart specialization and effective communication with various stakeholders in the regional context.

\section{Literature review}

IR is considered as a component of corporate transparency (Esterhuyse, 2019) and it is indissolubly related to online performance with company's investors. Here the author proposes to use legitimacy theory and voluntary disclosure theory in order to improve relations between investors and the enterprise.

It is also proved on the example of regression analysis of Islamic banks in the United Arab Emirates that actors with the higher index of information transparency have better indicators of operation activities (Tabash, 2019). At the same time the paper does not answer the question so long as it is possible to apply this methodology to the countries with emergency markets.

In the other paper it is assumed that effective IR via Internet resources leads to the optimal stock prices and increasing liquidity (Esterhuyse \& Wingard, 2016), while it needs to be specified what exact instruments should be used for reaching the mentioned indicators. Alves \& Silva (2020) regarded corporative communications via IR and related it to abnormal returns of the Portuguese companies. Very similar idea is in the article of Klagge B., Greiner C., Greven D., \& NwekeEze C. (2020), where they stress on importance of IR between investors and communities on the examples of Kenia. They prove that such relationship may enforce the utility of public-private partnership projects. In furtherance of the cross-country peculiarities there is also research on IR in Indo-Nepal region (Taneja,
Prakash, Bimal, Garg, \& Roy, 2020), where authors claim about friendly and warm relationship between Indian and Nepali business. However, there is no reason to generalize all the relationship between companies and investors, because problems happen in every business. Some researchers consider financial reporting documents as a formal IR tools, in addition, they reveal non-formal financial tools (Grigoraș-Ichim et al., 2018).

Some studies on IR are related to corporate social responsibility. For instance, Murashima (2020) finds that CSR-related news influence investors' behaviors differently based on their goals, ability and access information. Other research tends to conclude that IR domain is the specifics of IPO process as a large business peculiarity (Chahine, Colak, Hasan, \& Mazboudi, 2020). Moreover, Shkarlet \& Dubyna (2017) relate financial trust to investor attractiveness of the companies at different levels (micro-, meso-, macro).

Nel \& Brummer (2016) designed a methodic, which allows to measure IR strategy and its effectiveness, was proved by assessment of the listed companies. Then they continue to research IR issues (Nel, Smit and Brummer, 2018) and confirm that there is a correlation between well-designed Internet IR strategy and decreasing of financial asymmetry. Later, the scientists considering the data of the Johannesburg Stock Exchange reveal the correlation between implemented IR Strategy and the cost of capital (Nel, Smit and Brummer, 2019).

A relationship exists between using of IR resources by traders of the stock market and the likelihood of contract conclusion (Upton, 2018), at the same time author sums up that IR companies make an impact on market reactions, and their presence can lengthen the process of M\&A.

There is a certain number of researches where modern skills and knowledge for IR-managers are regarded. It is revealed that today IR manager is considered as a person who builds confidential relations between investors and companies, sets up two-way communication, responds to requested information, ensures adjusting the interests and expectations of investors (Hašček, 2017). In additions, the researcher claims that modern IR manager should have knowledge in finance, law and marketing area. The attention is also paid to the issue of social media usage (Twitter and $\mathrm{Fb}$ ), whereas the IR instruments, which should be used, are slightly mentioned.

Continuing the topic of the IR professional skills there is a need to mention the paper of Camiciottoli (2020). The author proves the importance of good command of English in international business. Here she measures the effectiveness of such IR specialists on the finance international deals. Karolyi, Kim \& Liao (2020) studied a set of companies from different countries and revealed other additional IR functions (the firm's interactions with brokers and investors, the formulation of its disclosure policies, and its global outreach efforts). 
From recent time IR is considered on communicational approach in modern economy (Gackowski, 2017). The idea of mentioned research is to represent reputational approach of IR, which includes financial and non-financial features. Despite the theoretical character of the article, the author describes the difference between investor relations and public relations, but the study should be filled up by the empirical data.

The opportunities, risks, and tensions of IR are regarded by scientists in PR and finance (Doan and McKie, 2018). Here the authors offer to regard IR as an instrument of risk management during equity crowdfunding (ECF). They state obvious to begin to work with IR-instruments, however it is not enough to satisfy the information requirements of investors and they admit the increasing potential of IR in order to improve corporate dialog between investors and companies.

Among scientific research in IR area, the attention should be paid to the paper, where four-dimensional framework is offered to evaluate the extent of IR on the
Web (Halim, Basiruddin and Ali, 2015). At the same time, the paper suffers from the lack of explanation how they propose to improve the communication with investors using integrated platform.

\section{Methods and data research}

The research strategy is related to examining of IR specifics of the Ukrainian companies and its applicability for business in the context of smart specialization. The systemic and analytical methods are used for building investor relations system tools and to reveal the most often used tools of IR in the Ukrainian companies. Research was conducted based on the latest studies and processes taking place in the field of investment over the last 3 years. The base of the issuers was selected as the basis for research. Analysis of securities issuers according to data published by the National Commission on Securities and Stock Market of Ukraine was provided. Then every chosen issuer's IR online tools were studied. As a result, the base of issuers with the most popular IR tools was formed.
IR goals: strengthening shareholder involvement; improving information disclosure and company reliability; providing up-to-date compliance and corporate governance; reaching optimal valuation and enhance market capitalization as well as liquidity;

increasing company performance transparency and research coverage.

IR activities: company events for shareholders as well as special investor days with announcement of quarter/annual company results; relevant web-site management as well as social media including financial and non-financial content;

communication with investors through mailing, calls

including video; other events for investors: conferences, roundtables, competitions; interdepartmental connectivity.

IR principles: Commitment
(dedicating responsibility of top
management to IR department);
Coherence (communication policy
regardless the level of company
profitability);
Credibility (IR department should be
authorized representative of company
both for investors as well as for internal
departments);
Transparency and Clarity
(communication messages, strategy and
key point should be accurate and
accessible);
Two-way communication
(minimization of information
asymmetry)

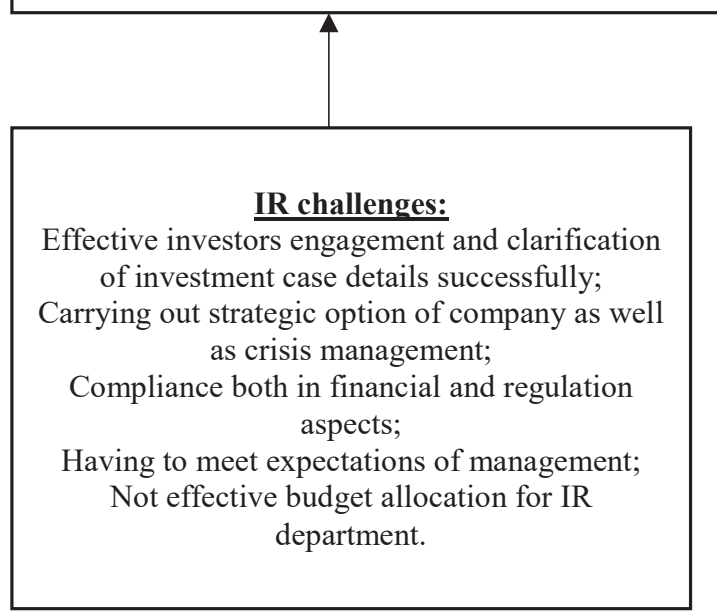

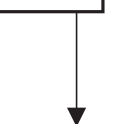

Benefits of IR for company:

Conducting negotiations regarding creating group of company supporters and adherents; Providing fair company valuation on the market; Raising capital through equity markets;

Providing stability of share price, decisionmaking in order to avoid its volatility;

Conducting strategic planning on the basis of company valuation forecasts;

Simplification of access to finance at a lower price.

Figure 1. IR as interface between company and financial market

Source: based on Crockett, T. (2011), Nel, G. F., \& Brummer, L. M. (2016), Hoffmann, C. P., Tietz, S., \& Hammann, K. (2018) 


\section{Results}

\subsection{Investor relations enabler as mediation between company and investors}

Investor relations (IR) could be considered as the specified channel aimed at providing two-way interaction between a company and financial markets as well as providing feedback loop from investors regarding company performance, strategic priorities, prospects, etc., which could be beneficial to decision-making processes and their adaptation to the market conditions and responses as well as improving communication effectiveness.

It should be emphasized that IR is not similar to public relations (PR) and marketing with aim to make company presentation in as such a positive way as possible, while IR is directed to strengthen investors understanding the specifics of business and some strategic and financial indicators as well as to provide fair awareness about company to all investor groups.

The fundamentals of effective IR policy with detailed explanation of the main goals, principles, conducted activities, possible benefits and challenges could be faced, are analyzed in Figure 1.

It is understood from Figure 1 that IR is a system and a huge instrument, which helps to struggle with different challenges face to modern companies. Therefore, the company receives some benefits from using of the IR toolkit.

Essential tools for effective IR regarding information disclosure are shown on Figure 2.

There are formal and informal requirements to disclosure of a company performance information. Those described at Figure 2 are commonly recognized and used by the companies. It is worth mentioning that these tools are suitable for large corporations and SMEs as well. At the same time, large companies websites have more functions (data base, analytics, webinars possibilities), however, SMEs look like digital visit-card and is more simply in using and searching information.

\subsection{Global trend and a place for development of IR in Ukraine in the context of smart specialization}

Due to the research of consulting organizations, there are several modern global trends in IR:

Investor relations help to develop not only big business, as it was before, but also startups and SMEs. Thus, startups actively use investor relations tools when entering an IPO.

MIFID 2 increases the burden on investor departments, as the role of intermediaries (brokers) is eroded. Investors are increasingly expressing a desire to

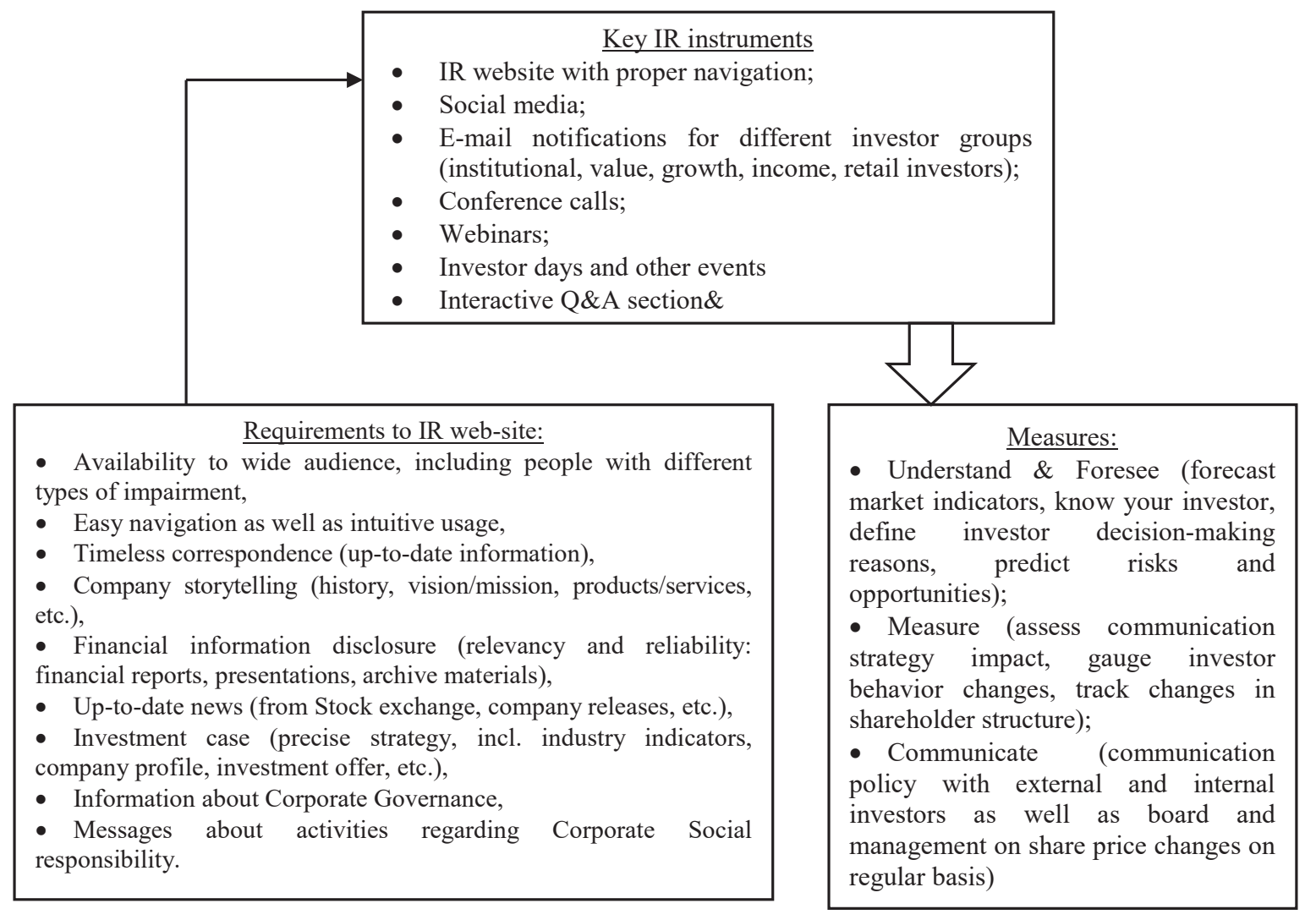

Figure 2. IR toolkit for company performance disclosure

Source: based on Crockett, T. (2011), Nel, G. F., \& Brummer, L. M. (2016), Hoffmann, C. P., Tietz, S., \& Hammann, K. (2018) 
communicate directly with investors. Because of this, the role of investor relations office is growing.

There is a need to develop digital tools (robo-advising); there are digital platforms for meetings with investors.

In recent years, there has been an increasing interest in investor relations in Ukraine. It is very important for Ukraine to develop investor relation and attract investments for financing perspective industry because Ukraine is a ground floor investment opportunitylocated in Europe, offering a highly skilled and productive workforce, low-cost manufacturing platforms and attractive entry valuations. Ukraine, located at the European Union's frontier, has a pro-Western, probusiness government focused on implementing reforms and strengthening the national economy and institutions. It is on its way to becoming an economic turnaround success account.

There are a few published researches on investor relations in Ukraine. However, with the educational system's strong focus on technical disciplines, Ukraine is home to the largest IT engineering force in CEE. International companies operating and expanding in Ukraine demand highly skilled workers and set high standards for the entire labour market. Over the last 10 years, use of English language has become more widespread, becoming an integral part of the education system and a key focus for the individual personal development.

However, there is the Ukrainian Association of Investor Relations that develops investor relation in Ukraine. The main goals of the Association are:

- Formation and development of the Investor Relations market in Ukraine;
- Introduction of the world practice of investor communication in the Ukrainian companies;

- Harmonization of the Ukrainian and international corporate disclosure standards;

- Assistance to the Ukrainian companies in obtaining foreign and domestic investments;

- Promoting professional development of IR professionals in Ukraine.

For a detailed analysis of IR trends among the Ukrainian companies, a sample of 262 non-financial companies was selected and grouped according to the ownership criterion.

The State-Owned group includes companies whose ultimate beneficiary is the government. Holdings group includes companies that are part of the large domestic holdings. The Domestic ownership group consists of companies owned by local owners. The Foreign ownership group includes companies that have foreign investments or are subsidiaries of international corporations.

The distribution of the sample is presented in Figure 3.

In addition, 9 IR tools were identified and used in analysis:

1. News releases and presentations.

2. Meetings with investors.

3. Annual report on the website.

4. Responding to queries.

5. Investor Roadshow.

6. Informal Meetings with Analysts \& Journalists.

7. Analytic days, Trip to the factories.

8. Conference participation.

9. Separate subpage on Investor relations.

10. Data source: sites of the surveyed companies.

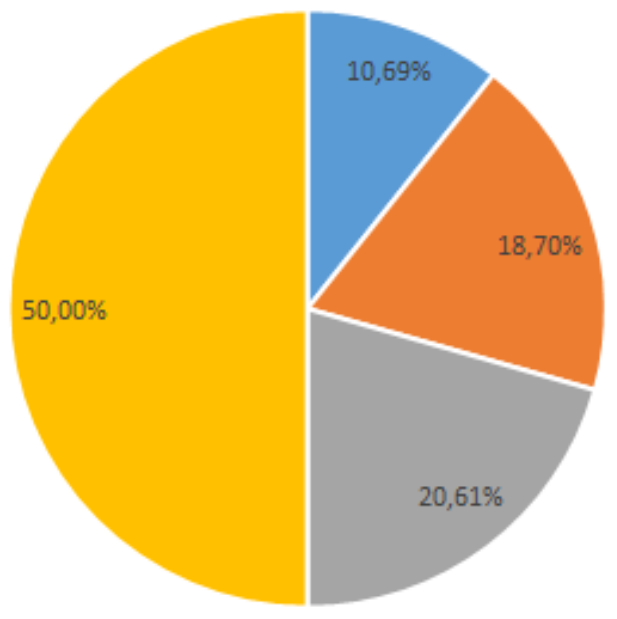

- State Owned | Holdings | Domestic ownership | Foreign ownership 


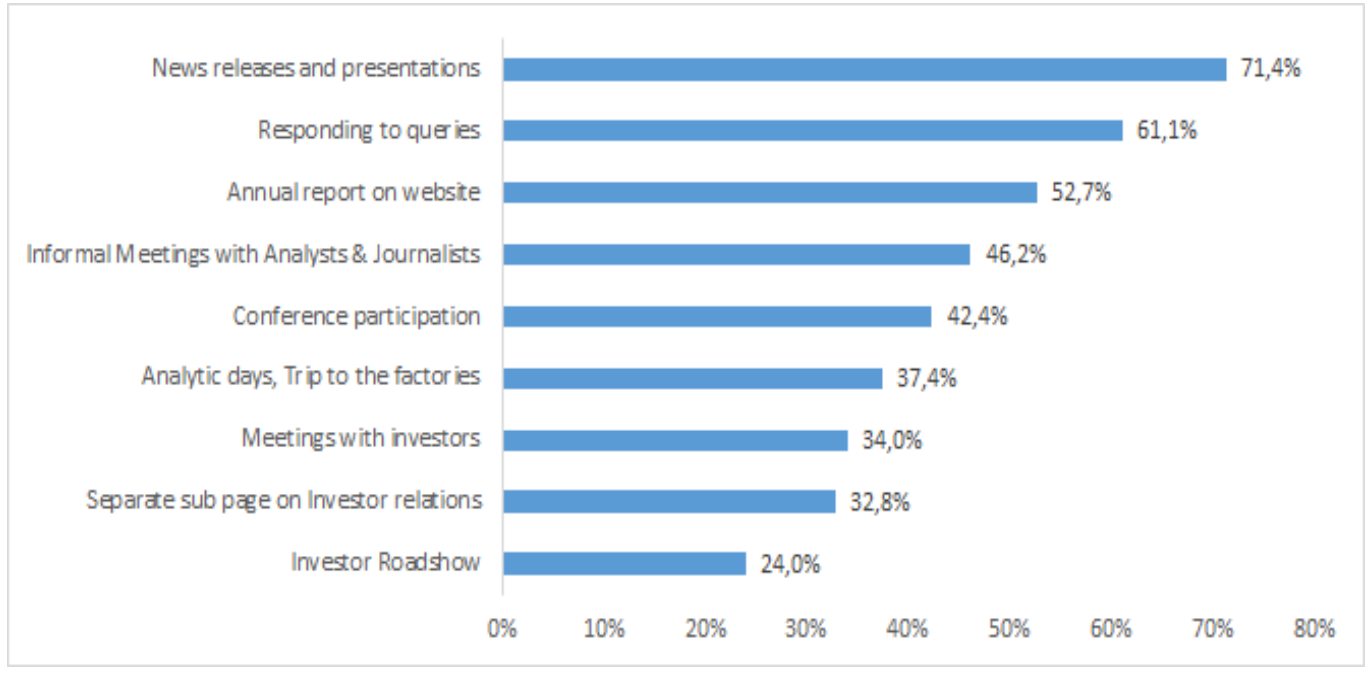

Figure 4. Distribution of IR tools among the studied companies

The study of the popularity of IR instruments among the Ukrainian-based companies was conducted in two directions. Firstly, the identification of the most popular tools among the 4 groups of companies. Secondly, determining the completeness used IR tools. An analysis of the distribution of IR tools shows that the most widespread are mainly information-oriented ones: publishing news about the company and responding to inquiries. Only a third part of companies have a separate page on the investor relations website.

The data from Figure 4 show that two groups of companies pay the most attention to IR: state-owned companies and companies that are part of domestic holdings. For example, they lead in publishing annual reports and responding to queries.

Local private companies, which have a limited number of owners, tend to disclose the least information.

Significant attention to IR tools by state-owned companies can be explained by the recent reform of corporate governance in the public sector, which was designed to make the work of such companies more transparent to society. The obtained results are additional evidence of the success of this reform.

Holding companies are either IPO companies or tend to attract resources from foreign financial markets through the issuing bonds or attracting debt from IFIs. Accordingly, the transparency of such companies will directly affect the cost and volume of financing obtained.

Since local private companies often have only a few owners, therefore, their relationship with the final beneficiaries is mostly non-public. The same is with foreign companies. As they mainly report to the parent company abroad, the disclosure requirements in the country of operating activities are not high (Table 1).

On average, the company uses only 4 of the 9 IR tools (Table 2). At the same time, local private companies and foreign companies are the least diversified: for them, the

Table 1

Distribution of IR tools among the studied companies

\begin{tabular}{|l|r|r|r|r|r|r|r|r|r|}
\hline $\begin{array}{c}\text { Type of } \\
\text { ownership }\end{array}$ & $\begin{array}{c}\text { News } \\
\text { releases and } \\
\text { presentations }\end{array}$ & $\begin{array}{c}\text { Meetings } \\
\text { with } \\
\text { investors }\end{array}$ & $\begin{array}{c}\text { Annual } \\
\text { report, } \\
\text { website }\end{array}$ & $\begin{array}{c}\text { Responding } \\
\text { to queries }\end{array}$ & $\begin{array}{c}\text { Investor } \\
\text { Roadshow }\end{array}$ & $\begin{array}{c}\text { Informal } \\
\text { Meetings } \\
\text { with } \\
\text { Analysts \& } \\
\text { Journalists }\end{array}$ & $\begin{array}{c}\text { Analytic } \\
\text { days, Trip to } \\
\text { the factories }\end{array}$ & $\begin{array}{c}\text { Conference } \\
\text { participation } \\
\text { sub page } \\
\text { on Investor } \\
\text { relations }\end{array}$ \\
\hline $\begin{array}{l}\text { State } \\
\text { Owned }\end{array}$ & $75.0 \%$ & $39.3 \%$ & $75.0 \%$ & $64.3 \%$ & $25.0 \%$ & $50.0 \%$ & $42.9 \%$ & $64.3 \%$ & $39.3 \%$ \\
\hline $\begin{array}{l}\text { Domestic } \\
\text { Holdings }\end{array}$ & $65.3 \%$ & $44.9 \%$ & $65.3 \%$ & $59.2 \%$ & $26.5 \%$ & $51.0 \%$ & $49.0 \%$ & $44.9 \%$ & $49.0 \%$ \\
\hline $\begin{array}{l}\text { Domestic } \\
\text { private } \\
\text { ownership }\end{array}$ & $66.7 \%$ & $27.8 \%$ & $53.7 \%$ & $61.1 \%$ & $22.2 \%$ & $42.6 \%$ & $33.3 \%$ & $27.8 \%$ & $18.5 \%$ \\
\hline $\begin{array}{l}\text { Foreign } \\
\text { ownership }\end{array}$ & $74.8 \%$ & $31.3 \%$ & $42.7 \%$ & $61.1 \%$ & $23.7 \%$ & $45.0 \%$ & $33.6 \%$ & $42.7 \%$ & $31.3 \%$ \\
\hline Sample & $71.4 \%$ & $34.0 \%$ & $52.7 \%$ & $61.1 \%$ & $24.0 \%$ & $46.2 \%$ & $37.4 \%$ & $42.4 \%$ & $32.8 \%$ \\
\hline
\end{tabular}


Vol. 6, No. 4, 2020

Baltic Journal of Economic Studies

Table 2

Distribution of IR tools used

\begin{tabular}{|l|c|c|c|c|c|c|c|c|c|c|}
\hline \multirow{2}{*}{\multicolumn{1}{c}{ Type of ownership }} & \multicolumn{9}{|c|}{ Number of IR instruments used } \\
\cline { 2 - 12 } & $\mathbf{0}$ & $\mathbf{1}$ & $\mathbf{2}$ & $\mathbf{3}$ & $\mathbf{4}$ & $\mathbf{5}$ & $\mathbf{6}$ & $\mathbf{7}$ & $\mathbf{8}$ & $\mathbf{9}$ \\
\hline State Owned & $17.9 \%$ & $14.3 \%$ & $0.0 \%$ & $3.6 \%$ & $3.6 \%$ & $17.9 \%$ & $14.3 \%$ & $21.4 \%$ & $3.6 \%$ & $3.6 \%$ \\
\hline Domestic Holdings & $16.3 \%$ & $6.1 \%$ & $2.0 \%$ & $12.2 \%$ & $20.4 \%$ & $6.1 \%$ & $6.1 \%$ & $14.3 \%$ & $6.1 \%$ & $10.2 \%$ \\
\hline Domestic private ownership & $14.8 \%$ & $7.4 \%$ & $13.0 \%$ & $14.8 \%$ & $20.4 \%$ & $7.4 \%$ & $9.3 \%$ & $5.6 \%$ & $3.7 \%$ & $3.7 \%$ \\
\hline Foreign ownership & $16.0 \%$ & $9.9 \%$ & $13.0 \%$ & $13.0 \%$ & $16.8 \%$ & $7.6 \%$ & $6.9 \%$ & $7.6 \%$ & $5.3 \%$ & $3.8 \%$ \\
\hline Sample & $16.0 \%$ & $9.2 \%$ & $9.5 \%$ & $12.2 \%$ & $16.8 \%$ & $8.4 \%$ & $8.0 \%$ & $9.9 \%$ & $5.0 \%$ & $5.0 \%$ \\
\hline
\end{tabular}

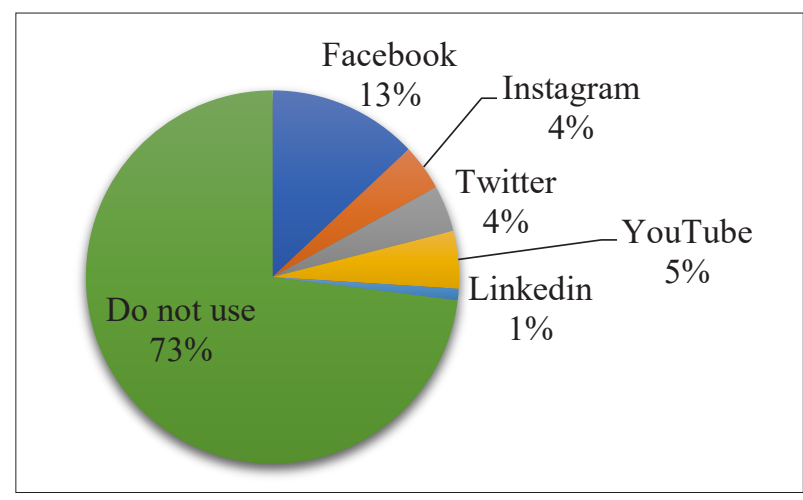

Figure 5. Distribution of companies by using social media

median values are 3.5 and 3 , respectively. The median value for state-owned companies is 5 .

Among the most used social networks are: Facebook $13 \%$, Instagram and Twitter - 4\%, YouTube $-5 \%$ and LinkedIn - $1 \%$. On average, social networks use only $25 \%$ of the total sample.

\subsection{Smart specialization and investor relations}

For the effectiveness of communications between different stakeholders involved in the investment process, you can use different tools of investor relations. Smart specialization, providing various communication activities promotes cooperation between the above participants in the investment process. Analyzing the data of the European Commission on activities that take place in the framework of smart specialization, we can identify the following key tools investor relations: online dialogues, online conferences, online sessions, online workshops, online presentations, world cafes, annual lectures, online consultations, webinars (partner webinars). It should be noted that the organizers of such meetings are either local authorities or representatives of civil society (this determines their role in the investment process). Smart specialization activities are essentially communication platforms for innovative businesses and inventors.

\section{Conclusions}

The research shows that there are several global trends in investor relations: 1) investor relations contribute to the transformation of startups and SMEs into large companies; 2) growing interest on the part of investors in direct communication with business, where they will invest (the institution of intermediation has weakened); 3) the emergence of online platforms for meetings with investors; 4) growing demand for alternative data from institutional investors (credit card sales, web scraping, web traffic, email scraping, social sentiment, satellite data); 5) increasing requirements for transparency of companies by investors, as well as the environmental and social components of their activities; 6) regional specifics and types of investors play huge role in choosing of investor relations tools.

The analysis of individual companies in Ukraine shows that different groups of companies apply investor relations policies differently. In our opinion, the determining factors of this process are the quality of corporate governance, the need for access to external financing markets and the number of shareholders. Thus, the recent reform of public sector enterprises has led to the strengthening of their supervisory boards, increased transparency, which is reflected in the strengthening of IR. On the other hand, companies that have one (or only several) owners do not need to increase IR.

Although investor relations of different companies are different, but the methods and tools of policy are the same. Smart specialization of regions, acting as a meeting place for investors, is also a tool for investor relations. And here it operates as a common tool for all key stakeholders involved in this process.

Further research should focus on different communication tools with different stakeholders.

\section{References:}

Alves, C. F., \& Silva, A. L. (2020). Corporate communication and media coverage of abnormal returns - evidence from the Portuguese capital market. Corporate Communications: An International Journal, Ahead-of-print (Ahead-ofprint). doi: $10.1108 /$ ccij-11-2019-0132 
Camiciottoli, B. C. (2020). Using English as a lingua franca to engage with investors: An analysis of Italian and Japanese companies' investor relations communication policies. English for Specific Purposes, 58, 90-101. doi: $10.1016 /$ j.esp.2020.01.003

Chahine, S., Colak, G., Hasan, I., \& Mazboudi, M. (2020). Investor relations and IPO performance. Review of Accounting Studies, 25(2), 474-512. doi: 10.1007/s11142-019-09526-8

Crockett, T. (2011). IR Best Practice \& the Tools Needed to Achieve it. Available at: https://www.belex.rs/ data/2011/03/00067100.pdf

Doan, M., \& McKie, D. (2018). Developing investor relations and strategic financial communication: Contemporary opportunities, risks, and tensions. Asia Pacific Public Relations Journal, 19, 1-15.

Esterhuyse, L. (2019). Towards corporate transparency. The Bottom Line, 32(4), 290-307. doi: 10.1108/bl-032019-0081

Esterhuyse, L., \& Wingard, C. (2016). An exploration of the online investor relations (IR) practices of companies listed on the Johannesburg Stock Exchange (JSE). South African Journal of Economic and Management Sciences, 19(2), 215-231. doi: 10.4102/sajems.v19i2.1261

Exploring how investor relations is organized in companies pre- and post-IPO. (2018). Available at: https://www.ey.com/Publication/vwLUAssets/EY_Taking_it_to_heart/\$FILE/ey-taking-it-to-heart-ir-survey.pdf Gackowski, T. (2017). The idea of investor relations in the modern economy: A communication approach. Economic Research-Ekonomska Istraživanja, 30(1), 1-13. doi: 10.1080/1331677x.2016.1265894

Grigoraș-Ichim, C. E., Cosmulese, C. G., Savchuk, D., \& Zhavoronok, A. (2018). Shaping the perception and vision of economic operators from the Romania-Ukraine-Moldova border area on interim financial reporting. Economic Annals-XXI, 173(9-10), 60-67. doi: 10.21003/ea.v173-10

Hascek, A (2017). Knowledge and skills of professionals in investor relations. Ekonomski Vjesnik, 30(2), 491-502. Halim, N. A., Basiruddin, R., \& Ali, N. R. (2015). Measuring the Extent of Investor Relations on the Web: A Multidimensional Approach. Procedia Economics and Finance, 31,714-721. doi: 10.1016/s2212-5671(15)01160-0

Hoffmann, C. P., Tietz, S., \& Hammann, K. (2018). Investor relations - a systematic literature review. Corporate Communications: An International Journal, 23(3), 294-311. doi: 10.1108/ccij-05-2017-0050

Investor Relations. Best Practice Toolkit (Working paper) (2018). Available at: https://www.tadawul.com.sa/wps/ wcm/connect/8a7e7d2d-6984-45fd-86a4-38a17d066a6e/IR+English.pdf?MOD=AJPERES\&CVID=mpSzZvj Investor relations: A strategic enabler (2019). Available at: https://assets.kpmg/content/dam/kpmg/in/pdf/ 2019/04/investor-relations-functions.pdf

Karolyi, G. A., Kim, D., \& Liao, R. (2020). The Theory and Practice of Investor Relations: A Global Perspective. Management Science, 66 (10), 4746-4771. doi: 10.1287/mnsc.2019.3405

Klagge, B., Greiner, C., Greven, D., \& Nweke-Eze, C. (2020). Cross-Scale Linkages of Centralized Electricity Generation: Geothermal Development and Investor-Community Relations in Kenya. Politics and Governance, 8(3), 211-222. doi: 10.17645/pag.v8i3.2981

Murashima, M. (2020). Do investors' reactions to CSR-related news communication differ by shareholder? An empirical analysis from Japan. Corporate Governance: The International Journal of Business in Society, 20(5), 781-796. doi: $10.1108 / \mathrm{cg}-11-2019-0346$

Nel, G. F., \& Brummer, L. M. (2016). The development of a measurement instrument to measure the quality of internet investor relations. South African Journal of Business Management, 47(4), 15-25. doi: 10.4102/sajbm. v47i4.71

Nel, G. F., Smit, E., \& Brummer, L. M. (2018). The link between Internet investor relations and information asymmetry. South African Journal of Economic and Management Sciences, 21(1). doi: 10.4102/sajems.v21i1.1966

Nel, G., Smit, E., \& Brümmer, L. (2018). The Impact of Internet Investor Relations on the Cost of Capital: Evidence from Companies Listed on the Johannesburg Stock Exchange. Australian Accounting Review, 29(1), 36-48. doi: 10.1111 /auar.12216

Reshetnikova, I., Smerichevskyi, S., \& Polishchuk, Y. (2019). Multican Marketing As An Innovation Technology Of Providing Services In TheConditions Of Globalization Of The Banking Market. Marketing and Management of Innovations, (3), 142-150. doi: 10.21272/mmi.2019.3-11

Shkarlet, S. M., \& Dubyna, M. V. (2017). Submission Of Mention Of The Category "financial Trust". Scientific Bulletin Of Polissia, 2(4(12)), 45-52. doi: 10.25140/2410-9576-2017-2-4(12)-45-52

Tabash, M. I. (2019). An Empirical Investigation on the Relation between Disclosure and Financial Performance of Islamic Banks in the United Arab Emirates. The Journal of Asian Finance, Economics and Business, 6(4), 27-35. doi: 10.13106/jafeb.2019.vol6.no4.27

Taneja, N., Prakash, S., Bimal, S., Garg, S., \& Roy, R. (2020). Indo-Nepal Trade and Investment: An Analysis. India Quarterly: A Journal of International Affairs, 76(2), 243-275. doi: 10.1177/0974928420917799

Upton, K. (2018). Investor Relations Role in Merger and Acquisition Activity. Quarterly Journal of Finance, 08(02), 1850006. doi: $10.1142 / \mathrm{s} 2010139218500064$ 